CREDIT Research Paper

CREDIT

No. $16 / 03$

\title{
Military Spending, Armed Conflict and Economic Growth in Developing Countries in the Post-Cold War Era \\ by
}

M Nusrate Aziz and M Niaz Asadullah

\begin{abstract}
This paper re-examines the causal impact of military expenditure on growth in the presence of internal and external threats for the period 1990-2013 using data from 70 developing countries. We find that differences in methods, model specifications, and the underlying estimation sample partly explain why past studies have differed in terms of the true effect of military spending. Estimates based on both cross-sectional and panel methods indicate that military expenditure negatively affects economic growth during the post-Cold War era. However, the effect is insignificant in the crosssectional OLS method and fixed effects model for the full sample and the low-income country sub-sample, respectively. Moreover, the effect of military spending on growth conditional upon conflict exposure is positive and significant across all specifications, albeit the result is specific to internal instead of external conflict.
\end{abstract}

JEL Classification: Internal and external armed conflict, military expenditure, economic growth.

Keywords: O11, H56.

Centre for Research in Economic Development and International Trade, University of Nottingham 


\section{CREDIT Research Paper}

No. $16 / 03$

\section{Military Spending, Armed Conflict and Economic Growth in Developing Countries in the Post-Cold War Era \\ by}

M Nusrate Aziz* and M Niaz Asadullah**

Outline

1. Introduction

2. Literature Review

3. Model Specification and Estimation

4. Data and Variables

5. Main Results

6. Conclusion

References

Appendices

\section{The Authors}

* School of Economics, University of Nottingham, Malaysia; and CREDIT, Nottingham, UK. E-mail: Nusrate.Aziz@nottingham.edu.my

** University of Malaya, Malaysia; Department of Economics, University of Reading, UK; and Centre on Skills, Knowledge and Organisational Performance (SKOPE), University of Oxford, UK; E-mail: m.niaz@um.edu.my

\section{Acknowledgements}

We would like to thank Aynur Alptekin, Wing Leong, David Prentice, Usman Khalid and seminar participants at Nottingham University (Malaysia campus) for very helpful comments and suggestions. All remaining errors are ours. 


\section{Introduction}

Military expenditure accounts for approximately 2.7 percent of global GDP and has been growing over time (SIPRI Yearbook 2010). It continuously fell after the end of the Cold War era (e.g., until 1998) before starting to increase again (see Appendix Figure 1). Although less pronounced, it has also increased in developing countries where governments underspend on social outcomes and the majority of the population live below one dollar a day. However, there is no consensus concerning the impact of military expenditure on economic growth, particularly for the post-Cold War period. Existing studies vary in terms of the theoretical approach, empirical methods, sample countries and the period over which military spending is studied.

Some studies argue that government spending on military hardware crowds out investment in economically productive sectors thereby lowering growth (e.g., see Smith, 1977, 1978, 1980; Rothschild, 1977; Lim, 1983; Deger and Smith, 1983; Landau, 1985; Leontief and Duchin, 1983; Dunne, Nikolaidou and Smith, 2002; Mintz and Huang, 1990; Ram, 1995). Others argue that military spending boosts business confidence in conflicting countries, which facilitates investment and economic growth (Benoit, 1978; Kennedy, 1974; Whynes, 1979; Barro and Sala-iMartin, 2004; Dunn, Smith and Willenbockel, 2005). Indeed, many studies suggest that military expenditure has a non-linear effect on economic growth conditional upon exposure to conflict (Aizenman and Glick, 2006; Cothren, 2002; Frederiksen and Looney, 1982; Landau, 1996). ${ }^{1}$

Following the end of the Cold War, the world entered into a new era of threats arising from rogue states, transnational territory networks and regional

\footnotetext{
1 For studies that have examined the non-linear effect of military spending conditional on other factors, such as corruption and the quality of institutions, see D'Agostini, Dunne, and Pieroni, 2012; Compton and Paterson 2015.
} 
conflicts. Although armed conflicts between nations have declined, countries continue to spend on defense due to various latent external threats to counter the nuclear, chemical, radiological and biological weapons accumulated by their rivals (Aizenman and Glick, 2006). In addition, many countries face continuous threats of internal conflicts. $^{2}$ As a matter of fact, intra-state (i.e. internal) armed conflicts - armed confrontations between the governments and organized opposition groups disproportionately occur within 50 countries, the majority of which belong to developing countries in Asia and Sub-Saharan Africa (Collier, 2007). Poverty is one of the most important structural conditions that facilitate such conflicts thereby making developing countries vulnerable to civil wars (Collier and Hoeffler, 2004). This can lead to a type of trap in which prolonged conflict exacerbates the conditions that favor insurgency by increasing poverty and destroying social and economic infrastructure. ${ }^{3}$ If the overall economic loss owing to conflicts is significant, ${ }^{4}$ military expenditure can aid growth by minimizing the loss. In this context, military expenditure may grow even in the absence of actual external conflicts with different implications for economic growth. ${ }^{5}$ At the same time, the higher allocation of government funds to build military capacity can displace pro-poor social spending in countries suffering from intra-state conflicts.

2 There are various political groups that frequently engage in acts of terrorism and/or militancy thereby threatening the domestic economy. Examples include the Democratic Forces for the Liberation of Rwanda (FDLR), Mai-Mai groups, National Congress for the Defence of the People (CNDP) and Patriotic Forces for the Liberation of Congo (FPLC) in Africa; and the United Liberation Front of Assam (ULFA) and the Liberation Tigers of Tamil Elam (LTTI) in Asia.

3 Only a small proportion of the post-conflict countries succeed in keeping the peace beyond the first 10 years and experience slow growth (Collier, 2007).

4 For empirical studies on the impact of conflict on economic growth and human development outcomes, see Barro and Lee (1994), Murdoch and Sandler (2002), Staines (2004), Koubi (2005), Daria (2009), and Gates, Hegre, Nygård, Mokleiv and Strand (2012).

5 Collier (1999) argues that civil wars are liable to be more damaging than international wars. Economic costs in the case of the latter vary with the geographical extent of the conflict and the destruction of the capital stock, the general disruption of commerce, and the disruption of the government's capacity to collect revenue and provide various social services. 
Research on the determinants of growth in developing countries, with a specific focus on the interaction between military spending and the nature of the underlying conflict, is lacking. ${ }^{6}$ Moreover, a large number of studies on military expenditure (except Mintz and Huang, 1990; Chowdhury, 1991; Dunne et al., 2002; Dunne 2012; and Dunne and Tian, 2015) rely on cross-sectional data, and, therefore, have ignored the time dimension of the effect of military expenditure on economic growth. Dunne et al. (2002) apply a static panel approach, while Chowdhury (1991) uses time series data to determine the bivariate Granger causality between military expenditure and growth. Both studies ignore the multivariate regression approach. On the other hand, Mintz and Huang (1990) employ a ridge regression estimator and GLS in time series data for the US. Dunne (2012), and Dunne and Tian (2015) apply the dynamic panel approach using the fixed effects model. While D'Agostini, Dunne, and Pieroni (2012), and Houa and Chena (2013) rely on the GMM method to address the possible endogeneity of military spending in the growth equation.

The above studies on the effect of military spending suffer from a number of limitations. First, most have not considered whether the expansion in military spending happens due to increased threat, i.e., they have not allowed for the nonlinear relationships in the defense expenditure augmented economic growth model. Second, the regression specifications employed in time-series and panel studies include level variables in most cases. However, the growth effect of military spending cannot be captured if only the level variables are used. Third, to the best of our knowledge, none of the studies on the effect of conflict and military expenditure have used dynamic estimation methods, such as system GMM, even though Blundell,

\footnotetext{
6 Two exceptions are Dunne (2012), and Dunne and Tian (2015); both use data that span the post-Cold War era (1988-2006 and 1988-2010, respectively).
} 
Bond, and Windmeijer (2000) show that in the case of the non-linear moment condition, the system GMM not only improves the precision but also greatly reduces the finite sample bias. Fourth, none of the studies test for a significant difference in the economic growth effect of military spending due to an external or internal threat. Lastly, none of the extant studies evaluated the nexus between economic growth and military expenditure for the entire post-Cold War era.

We therefore contribute to the literature in three ways. Firstly, we revisit the relationship between military expenditure and economic growth across countries suffering from armed conflicts. Similar to Aizenman and Glick (2006), we conclude that military expenditure and growth relation can be appropriately measured by only applying the non-linear growth model. In addition, we add to the literature, including Aizenman and Glick (2006), by examining whether the growth effect of the ratio of military expenditure and GDP (henceforth milex) is due to internal or external threat. To be precise, we formally test the hypothesis that an expansion in military expenditure due to internal and external conflict has different growth effects. Secondly, the selective use of data and econometric methods may explain why earlier studies are in disagreement concerning the impact of military expenditure on growth. We therefore re-examine the relationship between milex and growth by using a variety of methods - cross sectional OLS, pooled OLS, random effects, fixed effects models and system GMM. This way, our estimates not only generate comparable results, they also highlight the sensitivity of the effect of milex to the underlying estimation technique. Finally, we test how our results vary across countries of different income levels (e.g. low- vs. middle-income).

The rest of the paper is organized as follows. Section 2 provides an overview of the literature on military expenditure, conflict and economic growth. Section 3 
presents the methodological framework. Section 4 describes the data. Section 5 presents the main results while section 6 is the conclusion.

\section{Literature Review}

There is no consensus concerning the effect of military expenditure on economic growth in the existing literature. According to one set of studies, military expenditure creates positive externalities, such as developed infrastructure, peace and a secure climate for investment. Ram (1995) argues that the absolute negative effect of military expenditure should not be claimed because the defense studies have not properly modelled the potential positive externality effect of milex. The empirical evidence in support of this view comes from Benoit (1978), Kennedy (1974), Whynes (1979), and Barro and Sala-i-Martin, (2004). Among others, Shieh et al. (2002) point out that there is a certain optimal level of defense expenditure, which maximizes economic growth. In a more recent study, Yildirim and Öcal (2014) analyze the influence of military expenditure on economic growth for the time period 2000-2010 for a sample of 128 countries. Employing an augmented Solow model specification, the authors find that military expenditure has a positive effect on economic growth. However, in a study on 55 developing countries, Chowdhury (1991) cautions that the relationship between milex and economic growth should not be generalized because the actual relations vary across countries. Moreover, the earlier studies have mainly used cross-sectional data and OLS estimators, and, therefore, fail to capture the dynamic nature of the effect of military expenditure on economic growth.

Some recent studies have therefore revisited the issue using a regional sample and adopting a dynamic empirical framework. Kollias and Paleologou (2010) use various econometric techniques (fixed panel models, random coefficient models and a 
trivariate VAR model) to empirically examine the relationship among growth, investment and military expenditure in the case of the European Union-15. Their findings do not suggest any consistent quantitative relation between defense spending and growth. Turning to developing country studies, D'Agostini, Dunne, and Pieroni (2012) use five-year panel data on 53 African countries and confirm that large military spending is bad for growth. However, they also attribute the negative effect to corruption pointing out that combatting corruption is likely to directly increase the aggregate economic performance and indirectly reduce the negative impacts of military spending on growth. Dunne (2012) studies the economic effects of military spending using a cross-country panel dataset spanning 1988-2006. The author also examines the Sub-Saharan Africa (SSA) region that has suffered from a number of violent conflicts. The results indicate a significant negative short-run effect and insignificant long-run effect of milex on per capita income growth. Houa and Chena (2013) restrict analysis to 35 developing countries over the period of 1975-2009. They use the system Generalized Method of Moments (GMM) estimators and document a negative and significant effect of defense spending on economic growth in the sample countries. Dunne and Tian (2015) examine the impact of military expenditure on economic growth using the dynamic panel data method for the period 1988-2010. They find that milex has a negative effect on growth in the short and long run. Their research addresses the issue of group heterogeneity - sub-sample analysis indicates that milex has an adverse effect on the growth of countries for all income groups. Compton and Paterson (2015) present an updated analysis on the issue for the post-Cold War era (i.e., 1988 to 2010). They test the conditional relational between military spending and economic growth with a focus on institutions. Estimation is based on the system GMM dynamic panel and fixed effects estimators. The authors 
find that the effect of military spending on growth is generally negative or zero. In countries where institutions are weak, military spending is harmful for growth, and, at best, has no effect when taking place in a strong institutional environment.

Lastly, Musayev (2015) re-examines the relationship between military spending and economic growth with a focus on the direct and indirect effects of conflict, corruption, and natural resources on economic growth. The author finds that the impact of military expenditure on growth is generally negative. However, the effect is not harmful for countries facing higher internal threats once corruption levels are accounted for. ${ }^{7}$ This finding highlights the possibility that sample composition is important alongside the choice of methods when studying the effect of milex. As a matter of fact, there is one group of studies that document a conditional, non-linear effect of military expenditure on economic growth. ${ }^{8}$ Frederiksen and Looney (1982) suggest that expansion in military expenditure helps economic growth in resource-rich instead of resource-constrained LDCs. By applying a non-linear growth model, Cuaresma and Reitschuler (2006) find that milex negatively affects economic growth in countries that spend a relatively low amount of GDP on defense. Aizenman and Glick (2006) find that although military expenditure alone has a negative effect on economic growth, expanded military expenditure in the face of threat has a positive effect on economic growth.

\footnotetext{
7 Overall, these studies support or advocate a cut in the military expenditure on the ground that it creates space for productive social spending, and, hence, is good for growth - reduced milex brings "peace dividends" by freeing resources for productive investment in developed (Smith, 1977; 1978; 1980; Rothschild, 1977; Mintz and Huang, 1990), as well as developing countries (Lim, 1983). For earlier studies on this, also see Leontief and Duchin (1983), Deger and Smith (1983), Landau (1985), and Dunne, Nikolaidou and Smith (2002).

8 For country specific studies using time series data on defense expenditure and economic growth, see Kalyoncu and Yucel (2006) on Turkey and Greece, and Chen (1993). Kalyoncu and Yucel (2006) find uni-directional causality running from economic growth to defense expenditure for Turkey while Chen (1993) does not find any long-term equilibrium relationship between defense spending and real economic growth rate.
} 
Our review of the existing studies confirms that the extant literature is inconclusive on the relationship between milex and economic growth. Older studies relying on data from the Cold War period tend to find a positive effect. But these studies tend to rely more on cross-sectional methods and/or pool data over economically rich and poor countries (i.e., heterogeneous panel). The general findings in more recent studies that rely on dynamic models and panel data based estimates suggest that milex has a negative impact in the short-term economic growth but that the relationship is reversed or insignificant in the long-run. However, almost none of the existing studies examined the joint effect of armed conflict and military expenditure on growth with a focus on developing countries even though the effect of milex can vary depending on conflict exposure. Although Aizenman and Glick (2006) are an exception, they only employ an OLS estimator in a non-linear growth model, and rely on a sample comprising both developed and developing countries (i.e., heterogeneous sample) for the period 1989-98. The authors also do not distinguish between intra-state and interstate conflicts. It is possible that milex can help attenuate the effect of conflict, and, in the long-run, it positively affects economic growth by shortening the duration of conflict. For these reasons, the exact effect of military expenditure on growth has been often hard to detect in the existing literature. ${ }^{9}$ Whether milex impacts growth in the post-Cold War era, particularly in conflict-affected developing countries, therefore, remains an empirical question.

9 For instance, estimates for SSA countries that were involved in conflicts between 1988 and 2006 show no effect of military spending on growth (Dunne 2010). 


\section{Model Specification and Estimation}

Our theoretical framework is based on the basic setup of the Cobb-Douglas (C-D) production function in which growth depends on the supply components (such as labor, capital) and the security components (such as armed conflict and military expenditure) of production (see, Dunn, Smith and Willenbockel, 2005). In the simple C-D production function, the government has no role. However, the role of government cannot be ignored in respect of economic growth. Therefore, we have included the role of government in the theoretical framework of our study. Hence, including the political variables, the basic C-D can be extended as:

$$
Y=A L^{\alpha} K^{\beta} P^{\tau}
$$

where $\mathrm{A}$ is an exogenous factor (Harrod-neutral technology progress), $\mathrm{L}$ is labor and $\mathrm{K}$ is capital and $\mathrm{P}$ is political activity in the economy. Here, $\alpha, \beta$ and $\tau$ are shares of labor, capital and political activities in production, $\alpha>0$, and $\beta>0$, but the sign of $\tau$ is uncertain. Some political variables have a positive effect while others have a negative effect on economic growth. We assume two security variables - armed conflict (C) and military expenditure (M) - as our political variables. Military expenditure may take place to tackle any internal or external threat (see, Dunn, Smith and Willenbockel, 2005; Aizenman and Glick, 2006). Conflict may negatively affect economic growth. However, military expenditure may have two alternative effects, positive or negative. If military expenditure reduces government expenditure in the real sector, it negatively affects economic growth; however, if military expenditure increases confidence for investment (i.e., gives security for safe investment), it would positively affect economic growth. For example, if military expenditure builds-up confidence in investors, then local and international investors invest more under a secured economic environment. 
Specifying the economic and political variables we can write:

$$
Y=A L^{\alpha} K^{\beta} C^{\gamma} M^{\rho}
$$

Taking logarithm and giving both cross-section and time-series specification, we can re-write:

$$
\ln Y_{i, t}=\ln A_{i}+\alpha \ln L_{i, t}+\beta \ln K_{i, t}+\gamma C_{i, t}+\rho \ln M_{i, t}
$$

Similar to Aizenman and Glick (2006), we apply a non-linear multiplicative term in our model. This is because military expenditure may not necessarily always be autonomous; it might also be induced by internal or external threats. Equation (3) can be written as:

$$
\ln Y_{i, t}=\ln A_{i}+\alpha \ln L_{i, t}+\beta \ln K_{i, t}+\gamma \ln C_{i, t}+\rho \ln M_{i, t}+\omega \ln (C M)_{i, t}
$$

where, subscript $i$ stands for cross-section and $t$ for time series, $C M$ is the cross product of threat and military expenditure. If the number of casualty is used as a proxy for the armed conflict variable, we can take the logarithm of armed conflict. However, if armed conflict comes as a binary dummy variable, we cannot take the logarithm.

By incorporating the disturbance term and giving the growth model specification, equation (4) can be written as:

$$
\Delta \ln Y_{i, t}=\mu_{i}+\varphi \ln Y_{i, t-1}+\alpha \ln L_{i, t}+\beta \ln K_{i, t}+\gamma \ln C_{i, t}+\rho \ln M_{i, t}+\omega \ln (C M)_{i, t}+
$$

$\varepsilon_{i . t}$

Theoretically $\varphi=-1$, which may be empirically testable.

Our empirical model is therefore as follows. ${ }^{10}$

(5) $\Delta y_{i, t}=\mu_{i}+\varphi y_{i, t-1}+\alpha l_{i, t}+\beta k_{i, t}+\gamma C_{i, t}+\rho m_{i, t}+\omega(C m)_{i, t}+\varepsilon_{i, t}$

10 Dunne, Smith and Willenbocket (2005) also suggest applying the Aizenman and Glick $(2003,2006)$ type model in the military expenditure literature. 
where subscript $i$ stands for cross-section and $t$ for time series, $y$ is real income, $l$ is labor, $k$ is capital and GDP ratio, $m$ is military expenditure and GDP ratio. $C$ is armed conflict, i.e., whether or not there was conflict (in an alternative model, we used whether there was internal or external conflict or no conflict), $\mathrm{Cm}$ is the cross-term to test the effect of milex on growth in the presence of armed conflict.

It should be noted that if milex is considered as a substitute for other public investments, then any increase in milex will reduce investment in other public sectors. However, if milex is a complementary product, it will not reduce other public investment; rather it will complement to those investments. Our second empirical specification includes two dummies for internal and external armed conflicts where the omitted category is 'no conflict'. Hence, there is no potentiality of the 'dummy variable trap'.

We hypothesize that military expenditure may positively or negatively affect economic growth, and armed conflict may negatively affect economic growth. However, military expenditure in the presence of armed conflict fosters economic growth. If true, the interaction term of armed conflict and military expenditure should be positive (i.e., $\omega$ will be positive).

Both external and internal stability are highly influential factors for economic growth. If the economy is not politically stable (internally or externally) then the investors lose confidence for investment in that economy, and, therefore, economic growth falls. Internal conflict takes place within the geographical territory of a country, which may negatively affect economic growth. External conflicts may take place along the common border of two or more countries (such as the conflict between India and Pakistan in Kashmir), which may also negatively affect economic growth. Subsequently our conjecture about the parameters may be expressed as: 


$$
\begin{gathered}
\frac{\partial \Delta y}{\partial m}=\mu_{1}+\omega C ; \quad \mu_{1}>0, \omega>0 \text { [Armed conflict] } \\
\frac{\partial \Delta y}{\partial m_{\text {intra }}}=\mu_{2}+\pi C ; \quad \mu_{2}>0, \pi>0 \quad \text { [Internal conflict] } \\
\frac{\partial \Delta y}{\partial m_{\text {inter }}}=\mu_{3}+\vartheta C ; \quad \mu_{3}>0, \vartheta>0 \quad \text { [External conflict] }
\end{gathered}
$$

In order to estimate equation (5), we apply both cross-sectional and balanced panel estimates in which balanced panel estimators include pooled OLS, fixed effects, random effects and system GMM estimators. The cross-sectional regressions include data for 70 countries while the balanced panel include data for 60 countries $(\mathrm{N}=60)$ from 1990-2013 ( $\mathrm{T}=24)$. We also estimate our empirical model for low-income and middle-income groups. In addition to all conventional estimators we apply the system GMM approach. GMM is superior to Ordinary Least Squares (OLS) and Maximum Likelihood Estimation (MLE) in that the desirable statistical properties of OLS and MLE are not achieved unless the data are normally distributed. Secondly, the effect of milex may suffer from the reverse causality problem. ${ }^{11}$ Moreover, econometric estimation of growth models is usually undermined by the omitted variable and/or endogeneity problem. For example, higher capital investment leads to economic growth, but, at the same time, may be picking up the effect of good institutions. In addition, Glaeser et al. (2004) questions the exogeneity of institutional variables in growth models. Chong and Calderon (2000) find bi-directional causality between institutional measures and economic growth. In the presence of the endogeneity problem, OLS is not an appropriate estimator. The 2SLS estimator, on the other hand,

\footnotetext{
11 Furuoka, Oishi, and Karim (2014) find that the size of military expenditure in China expands in the process of economic transformation - the long-run relationship between military spending and economic growth is characterized by a unidirectional causality from economic development to military expenditure.
} 
while preferred, is inefficient if there is heteroskedasticity in the data. ${ }^{12}$ In contrast,

GMM is an efficient estimator even in the presence of heteroskedasticity (Siddiquia and Ahmed, 2013). Moreover, system GMM improves the precision and reduces the bias of the non-linear dynamic model (see, Blundell, Bond and Windmeijer, 2000). It is a computationally convenient method for estimating a non-linear dynamic model without complete specification of the probability distribution of data.

We therefore estimate equation (5) using standard dynamic panel estimators (OLS, fixed effects and random effects) and system GMM approach. We use lags of the endogenous variable as instruments in the regression. The second lag is appropriate because the first lag may be correlated with the current disturbance term. Our estimated Model 1 treats milex as an unconditional variable, while Model 2 and Model 3 specify military expenditure as a conditional variable, interacted with "armed conflict". Model 3 distinguishes between internal and external conflicts. ${ }^{13}$ All the variables except dummy are in logarithmic form. It may be argued that in the presence of heterogeneity in a panel (arising due to country specific differences in structural factors), the "Pooled Mean Group" (PMG) technique is more appropriate (Pesaran et

\footnotetext{
12 d'Agostino, Dunne, and Pieroni (2013) use conflict onset as an instrument for military expenditure in a panel of African countries for the period 1989-2010. The empirical analysis suggests that endogeneity is likely to be an important issue and using IV estimation provides a larger significant negative effect for military spending on growth than OLS. This suggests that earlier studies have underestimated the damaging effects of military spending. However, implementing the 2SLS/IV model is difficult because it is hard to find a variable that would serve as a satisfactory instrument, which is also the case in our dataset. One potentially credible instrument could be the milex of neighboring countries. In his analysis of the determinants of national defense budgets in the post-Cold War era using data for 124 countries, Skogstad (2015) finds evidence that defense budgets are positively spatially correlated - countries account for the military spending of other countries when setting their budgets. However, we do not have milex data for the neighbors of all our sample countries.

13 Our analysis of conflict and growth could suffer from the problem of reverse causality, e.g., poor countries being more likely to participate in a civil conflict. One solution is to study the relationship between growth and a lagged (instead of contemporaneous) measure of conflict. This approach can support causality claims as long as there is no serial correlation in war occurrence. To this end, Koubi (2005) excluded countries that were engaged in a war during the 1975-89 period as well as during the 1965-75 period (such as Israel and Syria). However, this approach is ad hoc and subject to the sample selection problem. Hence, we did not pursue this although we do not rule out the possibility of inverse causality.
} 
al., 1999). However, the issue of heterogeneity is less serious here since our sample already excludes high-income countries. Moreover, we apply a sub-sample analysis to reduce the heterogeneity within low- and middle-income countries. This splitting of the data by income level makes the sample even more homogenous, hence the PMG estimator is less relevant for estimation.

Lastly, existing research has used a variety of models to estimate the relationship between growth and military expenditure. Some studies have used crosssectional regression analysis whilst others have employed panel data methods. If lagged dependent variables also appear as explanatory variables, strict exogeneity of the regressors no longer holds. The Least Squares Dummy Variable (LSDV) approach is inconsistent for dynamic panel data with individual effects irrespective of whether we use fixed or random effects specification (Nickell 1981). In this context, the GMM approach is more appropriate (Arenallo and Bond, 1985). The selective use of data and econometric methods may explain why existing studies disagree on the impact of milex on growth. Therefore, we report estimates of the effect of military spending based on the GMM and other alternative estimators, such as cross-sectional, pooled, fixed effects and random effects regression models.

\section{Data and Variables}

The post-Cold War data from 1990 to 2013 for seventy low- and middleincome countries are used (the list of countries is in the appendix). Both conflicting and non-conflicting countries are included to avoid possible country selection bias. This is a balanced panel since we excluded all the developing countries for which data on some variables were unavailable. Forty-two countries in our sample have suffered from conflict. 
Our dependent variable is GDP growth rate. Other variables such as 'Labor' is the labor force of each country, 'Capital' is the real gross fixed capital formation (\% of GDP). All three variables are collected from the 'World Development Indicators' (WDI) of the World Bank. We have not included the human capital variable, because time series data for this variable for the period from 1990-2013 are not available in WDI for all cross sections. Although the Barro and Lee database includes human capital data for all countries, this dataset is collected for every fifth year. This, in turn, has increased our degrees of freedom and our focus to milex. Data on military expenditure and GDP ratio are from the SIPRI Military Expenditure Database (2015), Stockholm International Peace Research Institute, Sweden.

The data for armed conflict comes from the Uppsala Conflict Data Program. It is worth mentioning that the 'armed conflict' dataset does not consider any conflict as armed conflict unless there were 25 or more battle deaths in a year. We also classified the data into 'internal conflict' and 'external conflict'. If a conflict takes place inside the geographical territory of a country by internal people, then the conflict is defined as internal conflict. Internal conflict usually occurs between the government and one or more opposition groups within the country. However, if the conflict takes place between two different nations, then the conflict is considered as external conflict. Armed conflict is a dummy variable in our empirical models. It takes the value equals 1 (one) if there was conflict of any form (such as major, minor, internal or external) in the given year, and 0 (zero) otherwise. 
Figure 1: Military expenditure (as a \% of GDP) and GDP growth rate in sample countries, 1990-2013

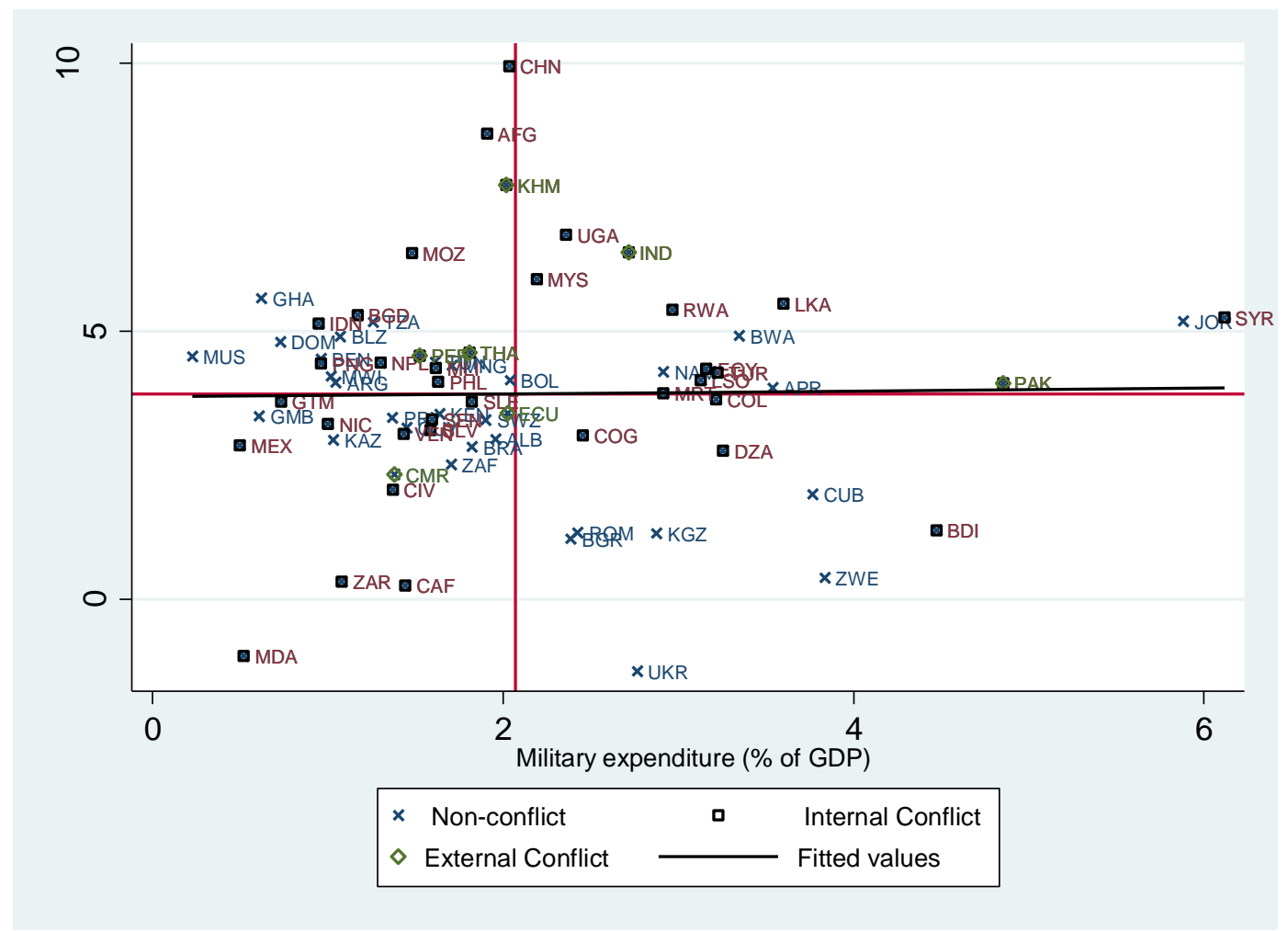

Note: Fitted line is based on linear regression of growth on military expenditure.

Our study sample includes 70 developing countries (see Appendix 1), which differ in terms of geographic location, size and rate of growth of GDP, and military expenditure and GDP ratio (see Appendix Table 2). The cross plot of milex and growth rate is presented in Figure 1. Contrary to popular perceptions, there is no clear correlation between growth rate and milex in the raw data. Conflict affected African countries, such as Senegal, have low milex while others (e.g., Rawanda) have high expenditure (see Appendix Figure 2). Nevertheless, growth is low in both countries during 1990-2000. However, Rawanda saw a jump in growth rate during 2001-2013 and a fall in milex suggesting a negative link between growth and milex. Uganda on the other hand, continues to enjoy growth despite conflict and significant milex. In South Asia, countries like Pakistan have remained trapped in the "low growth"-“high 
expenditure" quadrant throughout 1990-2013. The growth effect of milex is further complicated by the high level of military spending in a number of non-conflicting middle-income countries, such as China, Malaysia and Jordan during the post 2000 period. ${ }^{14}$ These countries spent more compared to poorer but (internal) conflict affected countries, such as Nepal, the Philippines, Senegal, Thailand, and Peru. To unravel the actual impact of milex on growth conditional on conflict exposure, we turn to econometric analysis in the next section.

\section{Main results}

As explained in section 3, our empirical analysis comprises two parts. First, we estimate the determinants of growth using four different naïve estimators - crosssection, pooled, fixed-effects and random effects models. For each, three alternative model specifications are used. The first model is a parsimonious one that examines the growth effects of military expenditure where we additionally control for labor and capital. Model 2 tests for the presence of a non-linear growth effect of military expenditure conditional upon exposure to armed conflict. Model 3 expands Model 2 by differentiating between external and internal conflicts. A number of findings follow from Table 1. First, consistent with the scatter plots of data on milex and growth (Figure 1 and Appendix Figures 2 and 3), there is a statistically insignificant relationship between milex and growth in the cross-section regression estimate (see Model 1). However, with control for the effect of conflict, the coefficient on milex becomes negative and significant. Second, milex exerts a systematically negative and significant influence on growth when we rely on dynamic models estimated using

14 Dunne (2012) finds the changes in milex to be insignificant for the upper middle-income countries during 1988 to 2006, implying that military expenditure is likely to be more damaging for poorer countries. 
fixed effects or random effects models. This is true irrespective of whether we use a parsimonious specification (i.e., model 1) or a detailed one (i.e., models 2 and 3) that accounts for the non-linear effect of milex. The negative coefficient on milex is significant across Models 1-3 when we apply the GMM estimator. ${ }^{15}$ However the coefficient is the smallest in size in this case.

The diagnostic test statistics indicate that the GMM estimates are robust. Specifically, the first and second order Arellano-Bond tests suggest that there is no first order or second order autocorrelation in the empirical models. The Sargan test results suggest that the instruments are exogenous in all specifications. The change in the estimated effect size of milex across cross-section, pooled, fixed effects, random effects and GMM estimates explains why the earlier studies on the effect of military spending, which, in most cases, relied on single methods using cross-section data, disagreed in terms of the results. When using panel data, they rarely employed all of these techniques, particularly GMM, and, consequently, have not produced the best results of the effect of milex on growth.

The third important result in Table 1 relates to the effect of conflict on growth. Irrespective of the estimation technique chosen, we find a negative coefficient on the conflict variable. However, the effect is only significant in the case of fixed effects and GMM estimators. This finding is consistent with recent research that also finds a direct negative effect of conflict on economic growth (e.g., Collier, 1999; Gates, Hegre, Nygård, Mokleiv \& Strand, 2012). Differentiating between external and internal threats reveals that conflict significantly harms growth when it is internal; the

\footnotetext{
15 Our results are partly consistent with Dunne and Tian (2015) who also employ post-Cold War data and find a negative and direct effect of military spending on growth. They do not examine the conditional effect of military spending. Instead they separately estimate the effect for conflict and nonconflict countries by employing the general first-order dynamic model and examine the direct effect of milex on growth, and find a negative effect in both.
} 
external conflict effect is rarely significant. ${ }^{16}$ Fourth, while milex on its own negatively affects growth, conditional on the presence of conflict, it has a positive and significant impact. This is only true in the case of internal conflict - if there is ongoing civil war, more military spending can protect the economy and contain the crisis leading to a positive growth effect. This again provides an additional explanation for the disagreement among older studies, as only some took into account exposure to conflict, and, even then, did not consider the interaction between conflict and milex.

Next we re-estimate the models separately for the low- and middle-income group samples. The results are reported in Table 2(a) and Table 2(b), which, once again, report three specifications altogether. In both low- and middle-income countries, military expenditure has a significant and negative growth effect irrespective of whether we control for conflict (except in the fixed effects model). In the low-income country sample, neither conflict matters for growth directly nor does it impact growth indirectly through influencing the level of military spending. On the other hand, it has a negative and significant impact on the middle-income country sample in GMM (see, Table 2(a)).

16 For studies that find the opposite result, see Aizenman and Glick (2006). 
Table 1: Cross-section and dynamic panel estimates of the determinants of economic growth, 1990-2013

\begin{tabular}{|c|c|c|c|c|c|c|c|c|c|c|c|c|c|c|c|}
\hline \multirow{3}{*}{ Lagged income } & \multicolumn{2}{|c|}{ Cross-section } & \multicolumn{4}{|c|}{ Pooled OLS } & \multicolumn{2}{|c|}{ Fixed Effects } & \multicolumn{4}{|c|}{ Random Effects } & \multicolumn{3}{|c|}{ GMM } \\
\hline & (1) & (2) & (3) & (1) & (2) & (3) & $\begin{array}{l}\text { (1) } \\
\end{array}$ & (2) & (3) & (1) & (2) & (3) & (1) & (2) & (3) \\
\hline & $-.39 *$ & -.29 & -0.27 & $-.49 * * *$ & $-.50 * * *$ & $-.50^{* * * *}$ & $-.98 * * *$ & $-.95^{* * * *}$ & $-.94 * * *$ & $-.58 * * * *$ & $-.57 * * *$ & $-.58 * * *$ & $-.19 * * *$ & $-.21 * * *$ & $-.22 * * * *$ \\
\hline & (.20) & $(.20)$ & $(0.20)$ & $(.12)$ & $(.12)$ & $(.12)$ & $(.31)$ & $(.31)$ & $(.31)$ & $(.171)$ & $(.17)$ & $(.17)$ & $(.02)$ & $(.03)$ & $(.03)$ \\
\hline Labour & $.26 * *$ & $.26^{*}$ & 0.21 & $.26^{* * * *}$ & $.69 * * * *$ & $.69 * * *$ & .64 & .52 & .46 & $.29 * *$ & $.31 * *$ & $.32 * *$ & $.16 * * *$ & $.16^{* * * *}$ & $.17^{* * * *}$ \\
\hline & (.13) & (.14) & (0.14) & $(.08)$ & (.143) & (.14) & (.76) & $(.76)$ & (.77) & (.12) & (.13) & (.13) & $(.03)$ & $(.03)$ & $(.03)$ \\
\hline Capital & $3.13^{* * * *}$ & $2.87^{* * * *}$ & $2.84 * * *$ & $3.34^{* * * *}$ & $3.52 * * *$ & $3.50^{* * * *}$ & $3.69 * * *$ & $3.65^{* * * *}$ & $3.62 * * *$ & $3.55^{* * * *}$ & $3.58 * * *$ & $3.56^{* * * *}$ & $.05 * *$ & $.05^{*}$ & .045 \\
\hline & $(.82)$ & $(.81)$ & $(0.81)$ & $(.33)$ & $(.34)$ & $(.34)$ & (.43) & $(.44)$ & (.44) & $(.38)$ & $(.39)$ & $(.39)$ & $(.03)$ & $(.03)$ & $(.03)$ \\
\hline Milex & -.05 & $-.84 *$ & $-0.89^{*}$ & $-.56 * * *$ & $-.71 * * *$ & $-.70^{* * * *}$ & $-2.03 * * *$ & $-2.24^{* * * *}$ & $-2.20 * * *$ & $-.97 * * *$ & $-1.14 * * *$ & $-1.13 * *$ & $-.19 * * *$ & $-.16^{* * *}$ & $-.10 * *$ \\
\hline & $(.35)$ & (.48) & $(0.47)$ & (.19) & $(.21)$ & $(.21)$ & $(.42)$ & $(.47)$ & (.46) & (.26) & (.29) & (.29) & $(.03)$ & $(.04)$ & $(.042)$ \\
\hline Conflict & & $\begin{array}{l}-.58 \\
(.59)\end{array}$ & & & $\begin{array}{l}-.49 \\
(.53)\end{array}$ & & & $\begin{array}{c}-1.40 \text { *** } \\
(.63)\end{array}$ & & & $\begin{array}{l}-.94 \\
(.58)\end{array}$ & & & $\begin{array}{l}-.60 * * * * \\
(.13)\end{array}$ & \\
\hline Internal Conflict & & & -0.39 & & & -.52 & & & $-1.59 * *$ & & & $-1.05 *$ & & & $-.51^{* * * *}$ \\
\hline & & & $(0.59)$ & & & $(.54)$ & & & $(.64)$ & & & (.59) & & & $(.14)$ \\
\hline External Conflict & & & 0.72 & & & -1.11 & & & -.93 & & & -.97 & & & $2.57^{* * * *}$ \\
\hline & & & (1.45) & & & (2.73) & & & (2.91) & & & (2.81) & & & $(.74)$ \\
\hline Milex*Conflict & & $\begin{array}{l}1.57 * * \\
(.69)\end{array}$ & & & $\begin{array}{l}.97^{*} \\
(.53)\end{array}$ & & & $\begin{array}{l}1.14 * \\
(.69)\end{array}$ & & & $\begin{array}{l}1.04 * \\
(.60)\end{array}$ & & & $\begin{array}{l}.35^{* * * *} \\
(.11)\end{array}$ & \\
\hline $\begin{array}{l}\text { Milex*Internal } \\
\text { Conflict }\end{array}$ & & & $1.67 * *$ & & & $.92 *$ & & & 1.11 & & & $1.01^{*}$ & & & $.28 * *$ \\
\hline & & & $(0.70)$ & & & (.54) & & & (.68) & & & (.60) & & & (.13) \\
\hline $\begin{array}{l}\text { Milex*External } \\
\text { Conflict }\end{array}$ & & & 0.29 & & & 1.16 & & & .53 & & & .90 & & & $-2.35 * * *$ \\
\hline Constant & $\begin{array}{c}-6.74 * * \\
(3.20)\end{array}$ & $\begin{array}{l}-6.16^{*} \\
(3.13)\end{array}$ & $\begin{array}{c}(1.75) \\
-5.54 * * \\
(3.6)\end{array}$ & $\begin{array}{c}-5.85 * * * \\
(1.63)\end{array}$ & $\begin{array}{c}-4.78 * * * * \\
(1.80)\end{array}$ & $\begin{array}{c}(2.08) \\
-4.81 * * *\end{array}$ & $\begin{array}{l}-8.199 \\
(11.67)\end{array}$ & $\begin{array}{c}-6.18 \\
(1170)\end{array}$ & $\begin{array}{r}(2.34) \\
-5.26 \\
(11.79)\end{array}$ & $\begin{array}{c}-6.13 * * \\
(2.40)\end{array}$ & $\begin{array}{c}-6.39 * * * \\
(2.41)\end{array}$ & $\begin{array}{c}(2.20) \\
-6.45^{* * *} \\
(2.45)\end{array}$ & $\begin{array}{l}-1.03 * * * * \\
(36)\end{array}$ & $\begin{array}{l}-.71^{*} \\
(37)\end{array}$ & $\begin{array}{c}(.59) \\
-.82 * * \\
(40)\end{array}$ \\
\hline No. of observation & 70 & 70 & 70 & 1438 & 1438 & 1438 & 1438 & 1438 & 1438 & 1438 & 1438 & 1438 & 1439 & 1439 & 1439 \\
\hline No. of countries & 70 & 70 & 70 & 60 & 60 & 60 & 60 & 60 & 60 & 60 & 60 & 60 & 60 & 60 & 60 \\
\hline $\begin{array}{l}\text { Arellano-Bond test } \\
\text { for AR(1) (p-value) }\end{array}$ & & & & & & & & & & & & & 0.54 & 0.04 & 0.003 \\
\hline $\begin{array}{l}\text { Arellano-Bond test } \\
\text { for AR(2) (p-value) }\end{array}$ & & & & & & & & & & & & & 0.99 & 0.80 & 0.61 \\
\hline Sargan test (p-value) & & & & & & & & & & & & & 0.97 & 0.98 & 0.99 \\
\hline Adj R-squared & 0.24 & 0.30 & 0.33 & 0.08 & 0.09 & 0.09 & 0.07 (о.a.) & 0.07 (o.a.) & 0.07 (o.a) & 0.08 (o.a.) & 0.08 (o.a.) & 0.08 (o.a.) & & & \\
\hline
\end{tabular}

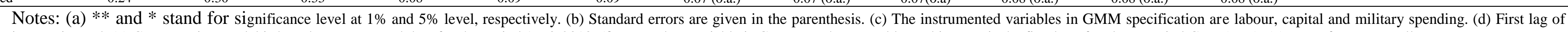
income is used. (e) Cross-section model is based on aggregated data for the period 1990-2013. (f) Dependent variable is GDP growth rate and lagged income is the first lag of real per capital GDP (PPP). (g) o.a. refers to overall. 
Most importantly, the effect of milex, which is conditional on conflict, is significant and positive in the middle-income country sample, and, particularly so in the case of internal conflict (in all estimators). This again highlights the fact that the estimated effect of milex is sensitive to sample composition - ignoring data on low-income countries can lead to a positive impact of milex, as is also evident in the scatter plot of raw data (see Figure 1). Lastly as an additional check of the sample heterogeneity test, we repeated the GMM analysis excluding China from the sample. This is because China has an unusually high growth rate, and, at the same time, has a high milex despite being a non-conflict country. However, our results relating to the effect of milex and conflict in the middle-income country sample remains unchanged.

Subsequently, we tested three hypotheses in Tables 1, 2(a) and 2(b) using a variety of methods. Our first hypothesis was that "the military expenditure without conflict may have a positive or negative effect on economic growth; however, in the face of conflict, an increased military expenditure fosters economic growth". The estimated results indicate that military expenditure negatively affects economic growth. Armed conflict also negatively affects (see, FE and GMM) economic growth. We point out that for the same data one can reach a different conclusion (i.e., conflict has a significant negative effect) if relying on cross-section and conventional dynamic panel estimators, such as OLS and random effects models. Our second hypothesis was that "any expansion in military expenditure due to internal and external conflicts affects the economic growth differently". The estimated results show that milex due to internal conflict has a significant positive effect while, generally, milex due to external conflict has an insignificant effect on economic growth. 
Table 2(a): Sub-sample Analysis, Pooled OLS and GMM

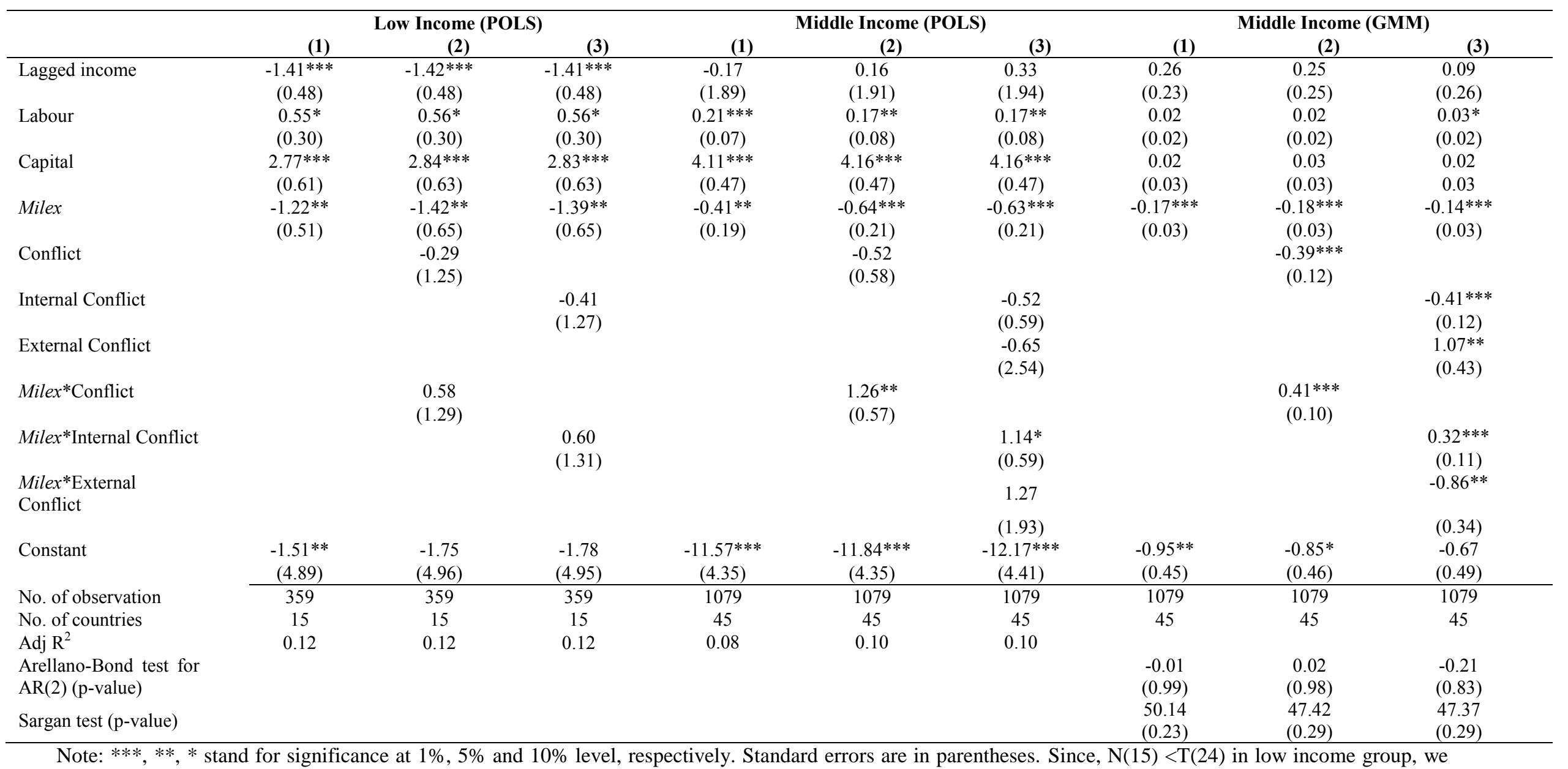

haven't applied GMM estimator in this case. 
Table 2(b): Sub-sample Analysis, Fixed Effects and Random Effects

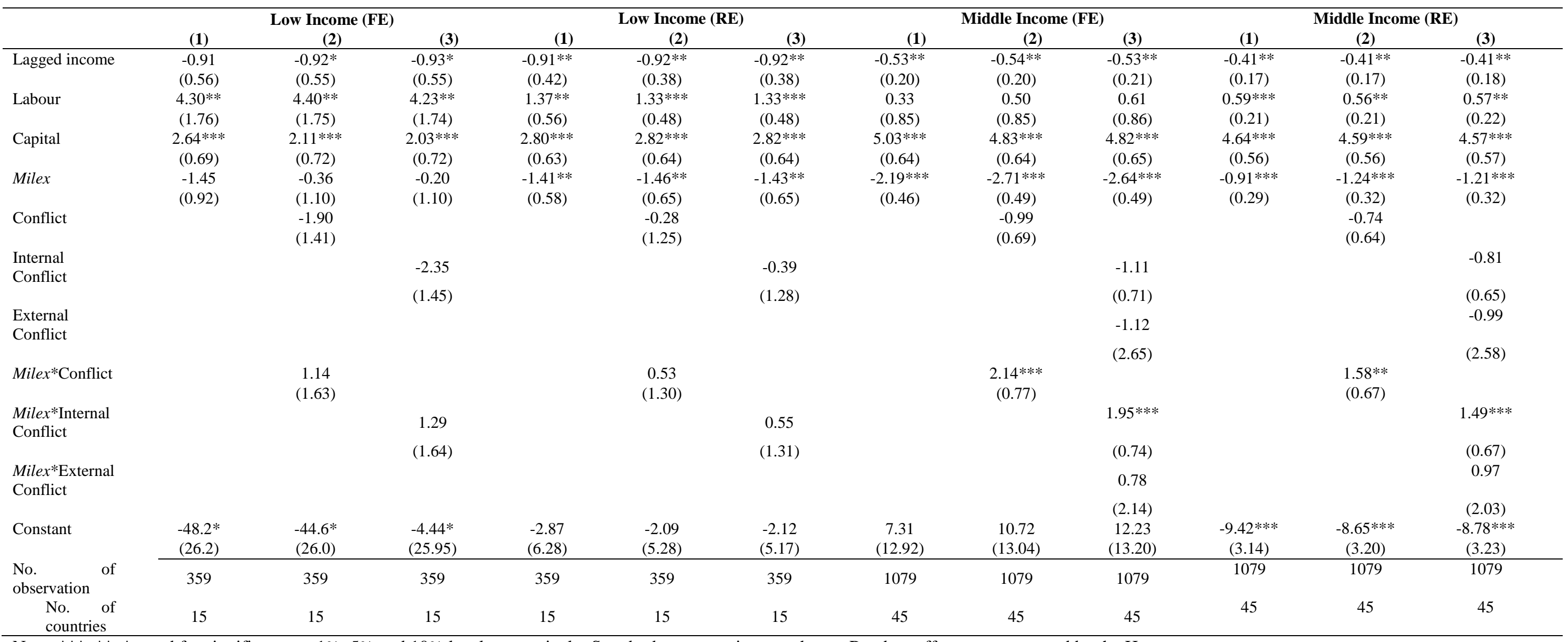

Note: $* * * * * *$ stand for significance at $1 \%, 5 \%$ and $10 \%$ level, respectively. Standard errors are in parentheses. Random effects are supported by the Hausman test. 
Clearly, different effects of milex exist due to internal and external conflicts. Hence, our second hypothesis is also supported by data. Our third hypothesis concerned the non-linearity condition of the economic growth model. We assumed that armed conflict alone may have a contemporaneous negative effect on economic growth. However, if milex takes place to protect the economy, then the combined effect would be positive on economic growth. In other words, military expenditure has a non-linear growth effect in the face of conflict. All the estimators indicate that once we impose the non-linearity condition, the interaction of military expenditure and internal conflict leads to a positive and significant effect on economic growth. This result remains robust to subsample analysis (for middle-income countries) with the exclusion of China. ${ }^{17}$

Our results provide some explanation for why previous research has failed to reach a consensus on the growth effect of military spending. Different researchers have used different empirical models to estimate the relationship between growth and milex. Some have used cross-sectional data and OLS regression analysis whilst others have employed panel data methods. Applying cross-sectional and panel data estimators that have been used in existing research, we find that relaxing the linearity assumption is key to observing the positive effect of military expenditure on economic growth. Our estimated results are in line with Aizenman and Dlick (2006) who estimated regression using OLS estimators. However, unlike Aizenman and Dlick (2006), we find a negative effect of conflict on economic growth if alternative estimators (fixed effects and GMM) are considered. We also find that middle-income countries (but not the LDCs) drive this result. Our analysis also isolates the effects of internal conflict from that of external conflict. We find that if military expenditure increases due to internal conflict, it has a significant positive effect on economic growth. If lagged dependent variables also appear as explanatory variables, strict exogeneity of the regressors no longer holds. The estimated

\footnotetext{
17 We also re-estimated the results for the middle-income country sample by excluding China from the dataset. This is because China has a very high growth rate and no ongoing external conflict, and yet has a sizable military expenditure. However, our findings on the non-linear effect of military spending were unchanged.
} 
effect of milex in such models will be inconsistent in the dynamic panel specification irrespective of whether fixed or random effects estimators are used. The GMM approach is more reliable and we document how the results change compared to non-GMM estimates. In other words, selective use of data and econometric methods may partly explain the disagreement among researchers in the older literature concerning the impact of milex on growth.

\section{Conclusion}

One of the reasons for the lack of consensus in the literature on the effect of military expenditure on growth is that studies have differed in terms of sample composition and the empirical models employed to examine the impact. Moreover, research focusing exclusively on developing country growth performance in post-Cold War period is lacking. Our study fills this gap by studying the growth effect of the post-Cold War armed conflict and military expenditure in the developing country context. The empirical specification distinguishes between external and internal conflict and relies on cross-sectional as well as a variety of dynamic panel models to capture the causal effect of military expenditure and its interaction with conflict. Since the sample countries are different in terms of income level, we also separately estimate the growth regression models for low- and middle-income countries.

The estimated non-GMM regression models show somewhat mixed support for the hypothesis that military expenditure has a significantly negative impact on economic growth - cross sectional OLS and low-income country fixed effects estimates of milex are insignificant). However, the effect is significant when conventional dynamic panel approaches (pooled OLS, fixed effects and random effects) and GMM estimates are considered. At the same time, allowing for an interaction effect between milex and conflict always leads to a positive and significant level effect of milex irrespective of the estimation technique chosen. We also find that expansion in military expenditure due to internal 
and external conflicts affect economic growth differently. The effect of military spending on growth conditional upon conflict exposure is significant and positive across all specifications albeit the result is specific to an internal instead of an external threat.

To conclude, a systematically negative effect of military spending on growth can be elusive even in the post-Cold War data unless we use appropriate econometric techniques and consider a sample that includes low- as well as middle-income developing countries. Moreover, analyses that do not take into account conflict exposure, a key driver of milex, can ignore the potentially beneficial role of military expenditure on growth. We show that the effect of military expenditure can be positive conditional on conflict exposure. Once again the statistical significance of this result varies depending on the econometric techniques employed. In other words, differences in methods, model specifications, and the underlying estimation sample partly explain why past studies have differed in terms of the true effect of military spending. Therefore, more studies using different sample and panel data methods should be carried out, which, together, may facilitate further investigation of the nexus between military expenditure and growth through meta-analysis. 


\section{References}

Aizenman, J. and Glick, R. (2006), Military Expenditure, Threats, and Growth, Journal of International Trade \& Economic Development, Vol. 15, No. 2, pp.129 - 155.

Alptekin, Aynur and Levine, P. (2012) "Military expenditure and economic growth: A meta-analysis," European Journal of Political Economy, vol. 28(4), pages 636-650.

Blackburne, Edward F. and Frank, Mark W. (2007), Estimation of nonstationary heterogeneous panels, The Stata Journal, 7(2), pp. 197-208.

Blundell, Richard; Bond, Steve; Windmeijer, Frank (2000): Estimation in dynamic panel data models: improving on the performance of the standard GMM estimator, IFS Working Papers, No. W00/12, http://dx.doi.org/10.1920/wp.ifs.2000.0012

Barro, R. J. and Sala-i-Martin, X. (2004), Economic Growth (second Edition), The MIT Press.

Barro, Robert J. and Jong-Wha Lee, (1994), Sources of Economic Growth, Carnegie-Rochester Conference Series on Public Policy, 40: 1-46.

Benoit, Emile (1978), Growth and Defense in Developing Countries, Economic Development and Cultural Change, 26: 271-80.

Brauer, Jurgen and Dunne, John P (2011) "On the Cost of Violence and the Benefit of Peace," Peace Economics, Peace Science, and Public Policy, vol. 16(2), 1-12.

Chan, Steve (1987), Growth with Equity: A Test of Olson's Theory for the Asian Pacific Rim Countries, Journal of Peace Research 24(2): 135-149.

Chen, Chien-Hsun (1993) Causality between Defence Spending and Economic Growth: The Case of Mainland China, Journal of Economic Studies, 20(6).

Chong, A., Calderon, C. (2000), Causality and feedback between institutional measures and economic growth, Economics and Politics, 12: 69 - 82.

Chowdhury, Abdur R. (1991), A Causal Analysis of Defense Spending and Economic Growth, The Journal of Conflict Resolution, 35 (1): 80-99.

Collier, Paul (1999), On the Economic Consequences of Civil War. Oxford Economic Papers, New Series 51(1):168-183.

Collier, P. and Hoeffler, A. (2004), Greed and Grievance in Civil War. Oxford Economic Papers, 56(4) 563-595.

Collier, Paul (2007) The Bottom Billion. Why the Poorest Countries are Failing and What Can Be Done About It. Oxford: Oxford University Press.

Cothren, R. (2002), A Model of Military Spending and Economic Growth, Public Choice, 110: 121-141.

Compton, Ryan and Paterson, Bryan (2015) "Military Spending and Growth: The Role of Institutions," Defence and Peace Economics, DOI: 10.1080/10242694.2015.1060022.

Deger, S. and Smith, R. (1983), Military Expenditure and Growth in Less Developed Countries, Journal of Conflict Resolution, 27 (2): 335-354.

Deger, S. and Sen, S. (1983), Military Expenditure, Spin-Off and Economic Development, Journal of Development Economics, 13: 67-83.

Deger, S. and Sen, S. (1995), Military expenditures and developing countries. In K. Hartley and T. Sandler (eds), Handbook of Defense Economics, Vol. 1. Amsterdam: Elsevier, pp. 275-307. 
D’Agostini, G., Dunne, J.P., and Pieroni, L. (2012) “Corruption, Military Spending and Growth,” Defence and Peace Economics, 23(2), 591-604.

D’Agostini,, Giorgio, Dunne, John Paul and Pieroni, Luca (2013) "Military Expenditure, Endogeneity and Economic Growth," MPRA Paper 45640, University Library of Munich, Germany.

Dunne, J Paul and Nan Tian (2015). "Military Expenditure, Economic Growth and Heterogeneity,", Defense and Peace Economics, 26(1), pp. 15-31.

Dunne, J. P. and Nan Tian (2013) "Military expenditure and economic growth: A survey," Economics of Peace and Security Journal, vol. 8(1), 5-11.

Dunne, J. P. (2012) "Military Spending, Growth, Development And Conflict," Defence and Peace Economics, vol. 23(6), pages 549-557, December.

Dunne, J. P. and Uye, M. (2010) "Military Spending and Development". In Tan, Andrew (ed.) The Global Arms Trade. Europa / Routledge: London.

Dunn, J.P., Smith, R.P. and Willenbockel, D. (2005) "Models of Military Expenditure and Growth: A Critical Review”. Defence and Peace Economics, vol. 16:6, 449-461.

Dunne, J. P., Nikolaidou, E. and Smith, R. (2002), Military Spending, Investment and Economic Growth in Small Industrialising Economies, South African Journal of Economics, 70(5): 789 - 808.

Frederiksen, P. C. and Looney, R. E. (1982), Defense Expenditures and Economic Growth in Developing Countries: Some Further Empirical Evidence, Journal of Economic Development, 7: 113-26.

Furuoka, Fumitaka, Oishi, Mikio and Karim, Mohd Aminul (2014) "Military expenditure and economic development in China: an empirical inquiry," Defence and Peace Economics, DOI: 10.1080/10242694.2014.898383

Glaeser, E. L., La Porta, R., Lopez-de-Silanes, F. and Shleifer, A. (2004) "Do Institutions Cause Growth?" Journal of Economic Growth, 9: 271-303.

Gates, S., Hegre, H., Nygård, Mokleiv, H. \& Strand, H. (2012), Development Consequences of Armed Conflict. World Development 40(9): 1713-1722.

Houa, Na and Chena, Bo (2013), "Military Expenditure and Economic Growth in Developing Countries: Evidence from System GMM Estimates," Defence and Peace Economics, pp. 183-193.

Kugler, Jacek and Marina, Arbetman (1989), "Exploring the Phoenix Factor with the Collective Goods Perspective," Journal of Conflict Resolution 33(1): 84-112.

Kennedy, G. (1974), The Military in Third Word, London: Duckworth.

Kollias, Christos and Paleologou, Suzanna-Maria (2010) "Growth, investment and military expenditure in the European Union-15," Journal of Economic Studies, 37(2).

Kalyoncu, Huseyin and Yucel, Fatih (2006) "An analytical approach on defense expenditure and economic growth: The case of Turkey and Greece," Journal of Economic Studies, 33(5).

Koubi, Vally (2005), War and Economic Performance, Journal of Peace Research, 42(1): 67-82.

Landau, Daniel (1985), Government expenditure and economic growth in the developed countries: 195276, Public Choice, 47: 459-477.

Landau, Daniel (1993), The Economic Impact of Military Expenditures, Working Papers 1138, Policy Research Department, The Word Bank. 
Landau, Daniel (1996), Is One of the 'Peace Dividends' Negative? Military Expenditure and Economic Growth in the Wealthy OECD Countries, Quarterly Review of Economics and Finance, 36: 183-195.

Leontief, Wassily and Duchin, Faye (1983), Military Spending: Facts and Figures, Worldwide Implications and Future Outlook, New York: Oxford University Press, p. 66.

Lim, D. (1983), Another Look at Growth and Defense in Less Developed Countries, Economic Development and Cultural Change, 31: 377-384.

Mintz, Alex and Huang, Chi (1990), Defense Expenditures, Economic Growth, and the "Peace Dividend", American Political Science Review, 84 (4): 1283 - 1293.

Murdoch, James C. and Todd Sandler (2002), Economic Growth, Civil Wars and Spatial Effects, Journal of Conflict Resolution 46(1): 91-110.

Musayev, Vusal (2015) Externalities in Military Spending and Growth: The Role of Natural Resources as a Channel through Conflict, Defence and Peace Economics, DOI:10.1080/10242694.2014.994833

Nickell, Stephen J. (1981), Biases in Dynamic Models with Fixed Effects, Econometrica, 49(6), 1417-26.

Pesaran, M.H., Shin, Y., Smith, R.P. 1999. Pooled mean group estimation of dynamic heterogeneous panels. Journal of the American Statistical Association, 94, 621-634.

Ram, R. (1995), Defense expenditure and economic growth. In K. Hartley and T. Sandler (eds), Handbook of Defense Economics, Vol. 1. Amsterdam: Elsevier, pp. 251-73.

Rothschild, Kurt W. (1977), Military Expenditure, Exports and Growth, Kyklos, 26: 804-13.

Siddiquia, D. A. and Ahmed Q. M. (2013), The effect of institutions on economic growth: A global analysis based on GMM dynamic panel estimation, Structural Change and Economic Dynamics, 24: $18-33$.

Shieh, Jhy-yuan, Lai, Ching-chong and Chang, Wen-ya (2002), The impact of military burden on long-run growth and welfare, Journal of Development Economics, 68: 443- 454.

Skogstad, Karl (2015) "Defence budgets in the post-Cold War era: a spatial econometrics approach," Defence and Peace Economics, DOI: 10.1080/10242694.2015.1034911.

Smith, R. P. (2000) "Defence Expenditure and Economic Growth", Chapter in Gleditsch, NP, Goran Lindgren, Naima Mouhleb, Sjoerd Smit and Indra de Soysa (eds.) Making Peace Pay: A Bibliography on Disarmament and Conversion. Regina Books, California, pp15-24.

Smith, Ron, Dunne, J. Paul and Nikolaidou, Eftychia (2000) "The econometrics of arms races," Defence and Peace Economics, vol. 11(1), pages 31-43.

Smith, R. (1977), Military Expenditure and Capitalism, Cambridge Journal of Economics, 1(1): 61-76.

Smith, R. (1978), Military Expenditure and Capitalism: A Reply, Cambridge Journal of Economics, 2(3): 299-304.

Smith, R. (1980), Military Expenditure and Investment in OECD Countries, Journal of Comparative Economics, 4(1): 19-32.

Staines, N. (2004), Economic Performance Over the Conflict Cycle. IMF Working Paper WP/04/95.

Whynes, D.K. (1979), The Economics of Third World Military Expenditure, London: MacMillan.

Yildirim, Jülide and Öcal, Nadir (2014) "Military expenditures, economic growth and spatial spillovers," Defence and Peace Economics, DOI: 10.1080/10242694.2014.960246 
Appendix Table 1: List of sample countries in the cross-section sample

\begin{tabular}{|c|c|c|c|c|c|}
\hline Name & code & Name & Code & Name & code \\
\hline Afghanistan & AFG & Ecuador & ECU & Nicaragua & NIC \\
\hline Albania & ALB & Gambia & GMB & $\begin{array}{l}\text { Pakistan } \\
\text { Papua New }\end{array}$ & PAK \\
\hline Algeria & $\mathrm{DZA}$ & Ghana & GHA & Guinea & PNG \\
\hline Argentina & $\mathrm{ARG}$ & Guatemala & GTM & Paraguay & PRY \\
\hline Bangladesh & BGD & Guyana & GUY & Peru & PER \\
\hline Belize & BLZ & India & IND & Philippines & PHL \\
\hline Benin & BEN & Indonesia & IDN & Romania & $\mathrm{ROM}$ \\
\hline Bolivia & BOL & Jordan & JOR & Rwanda & RWA \\
\hline Botswana & BWA & Kenya & KEN & Senegal & SEN \\
\hline Brazil & BRA & $\begin{array}{l}\text { Kazakhstan } \\
\text { Kyrgyz }\end{array}$ & KAZ & Sierra Leone & SLE \\
\hline Bulgaria & BGR & Republic & KGZ & South Africa & $\mathrm{ZAF}$ \\
\hline Burundi & BDI & Lesotho & LSO & Sri Lanka & LKA \\
\hline Cambodia & KHM & Malawi & MWI & Swaziland & SWZ \\
\hline $\begin{array}{l}\text { Cameroon } \\
\text { Central } \\
\text { African }\end{array}$ & CMR & Malaysia & MYS & Syria & SYR \\
\hline Republic & CAF & Mali & MLI & Tanzania & TZA \\
\hline China & $\mathrm{CHN}$ & Mauritania & MRT & Thailand & THA \\
\hline $\begin{array}{l}\text { Colombia } \\
\text { Congo, Dem. }\end{array}$ & $\mathrm{COL}$ & Mauritius & MUS & Tunisia & TUN \\
\hline Rep. & ZAR & Mexico & MEX & Turkey & TUR \\
\hline Congo, Rep. & $\mathrm{COG}$ & Moldova & MDA & Uganda & UGA \\
\hline Cote d'Ivoire & CIV & Mongolia & $\mathrm{MNG}$ & Ukraine & UKR \\
\hline $\begin{array}{l}\text { Cuba } \\
\text { Dominican }\end{array}$ & CUB & Morocco & APR & Venezuela & VEN \\
\hline Republic & DOM & Mozambique & MOZ & Zimbabwe & ZWE \\
\hline Egypt & EGY & Namibia & NAM & & \\
\hline El Salvador & SLV & Nepal & NPL & & \\
\hline
\end{tabular}


Appendix Table 2: Descriptive Statistics

\begin{tabular}{|c|c|c|c|c|c|c|}
\hline Sample & Variable & & Mean & $\begin{array}{l}\text { Std. } \\
\text { Dev. }\end{array}$ & Min & Max \\
\hline \multicolumn{7}{|l|}{$1990-2013$} \\
\hline \multirow[t]{5}{*}{ Full Sample $(\mathrm{N}=70)$} & Growth Rate & & 3.84 & 1.95 & -1.34 & 9.94 \\
\hline & $\begin{array}{l}\text { GDP Per Capita, } \\
\text { (constant } 2011 \text { Int. } \$ \text { ) }\end{array}$ & PPP & 5814.55 & 4313.98 & 628.64 & 16412.10 \\
\hline & Milex ( $\%$ of GDP) & & 2.07 & 1.21 & 0.23 & 6.11 \\
\hline & Labour (million) & & 27.80 & 99.10 & 0.10 & 725.00 \\
\hline & Capital/GDP & & 21.04 & 5.70 & 10.73 & 43.62 \\
\hline \multirow{5}{*}{ Conflicting (N=42) } & Growth Rate & & 4.09 & 2.13 & -1.05 & 9.94 \\
\hline & $\begin{array}{l}\text { GDP Per Capita, } \\
\text { (constant } 2011 \text { Int. \$) }\end{array}$ & PPP & 4878.25 & 4314.48 & 682.45 & 16412.10 \\
\hline & Milex (\% of GDP) & & 2.15 & 1.18 & .50 & 6.11 \\
\hline & Labour (million) & & 40.70 & 126.00 & 0.78 & 715.00 \\
\hline & Capital/GDP & & 21.15 & 6.41 & 10.73 & 43.62 \\
\hline \multirow[t]{5}{*}{ Non-conflicting ( $\mathrm{N}=28)$} & Growth Rate & & 3.47 & 1.60 & -1.34 & 5.62 \\
\hline & $\begin{array}{l}\text { GDP Per Capita, } \\
\text { (constant } 2011 \text { Int. \$) }\end{array}$ & PPP & 7218.99 & 3985.47 & 628.64 & 13726.82 \\
\hline & Milex (\% of GDP) & & 1.96 & 1.25 & 0.23 & 5.88 \\
\hline & Labour (million) & & 8.58 & 16.50 & 0.10 & 86.50 \\
\hline & Capital/GDP & & 20.87 & 4.53 & 11.88 & 29.25 \\
\hline
\end{tabular}


Appendix Figure 1: The Post Cold War Growth of Military Expenditure (1988-2014)

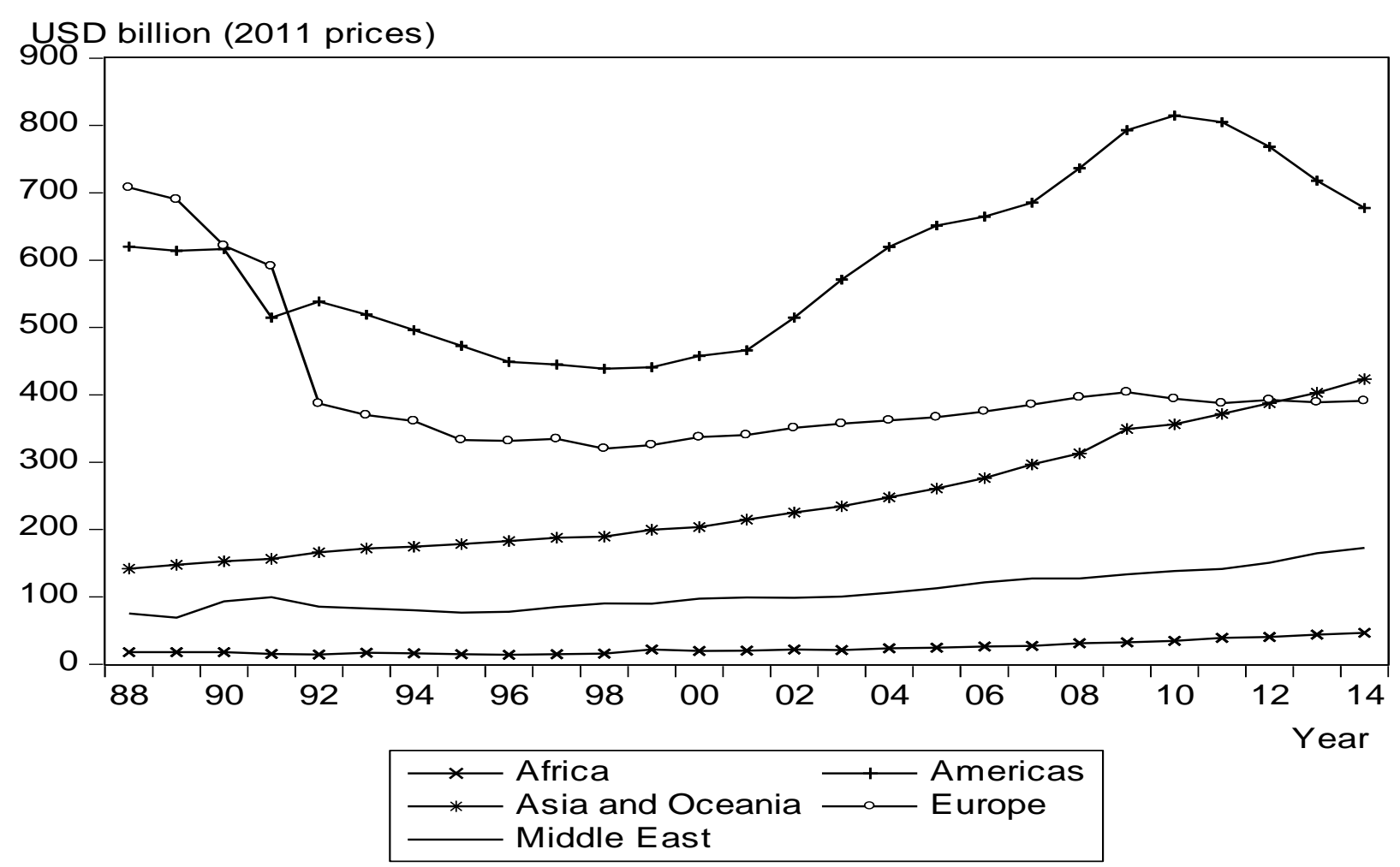

Data source: SIPRI 2015 
Appendix Figure 2: Military expenditure (as a \% of GDP) and GDP growth rate, Conflict Sample, 1990-2013

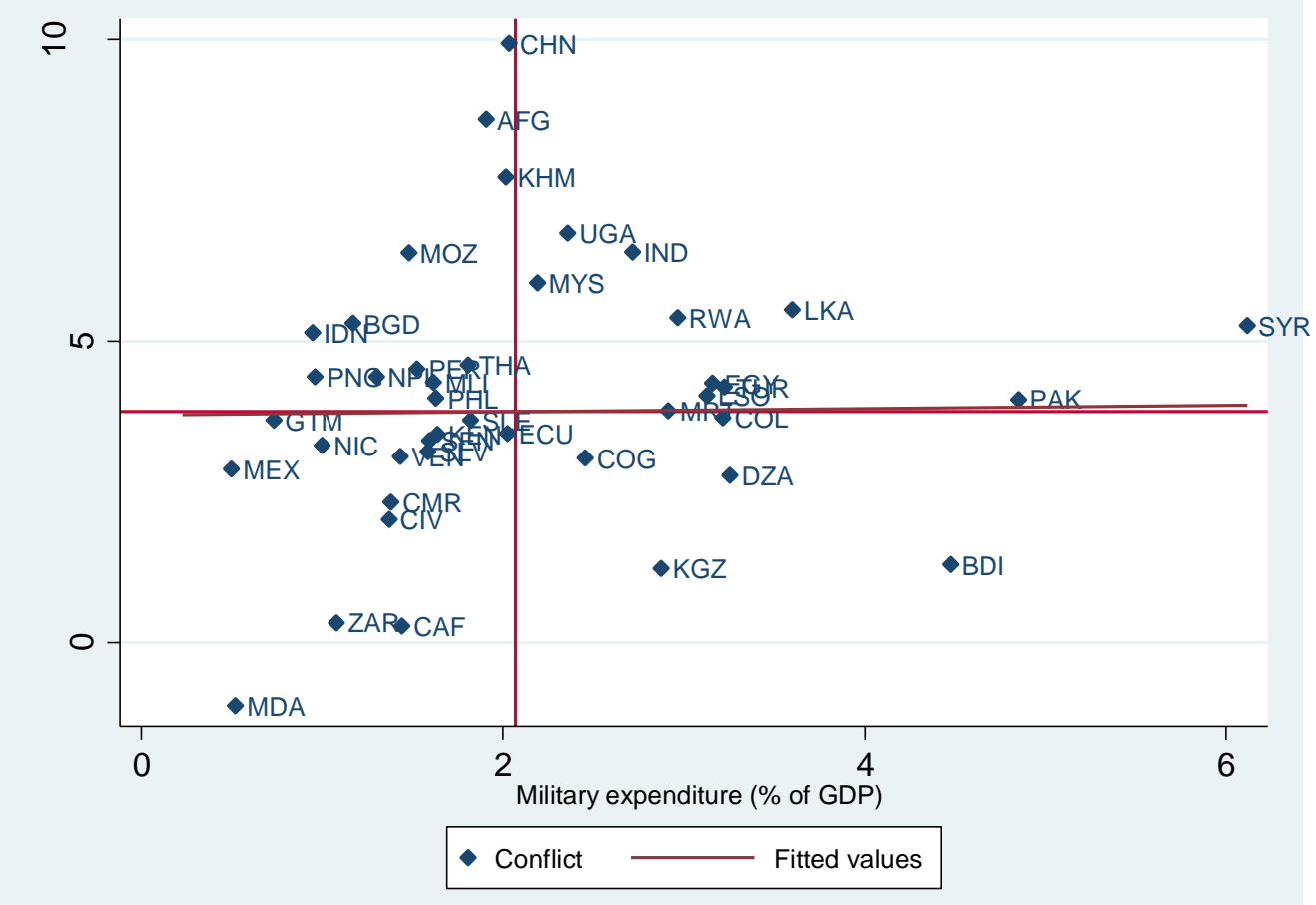

Appendix Figure 3: Military expenditure (as a \% of GDP) and GDP growth rate, Non-conflict Sample, 1990-2013

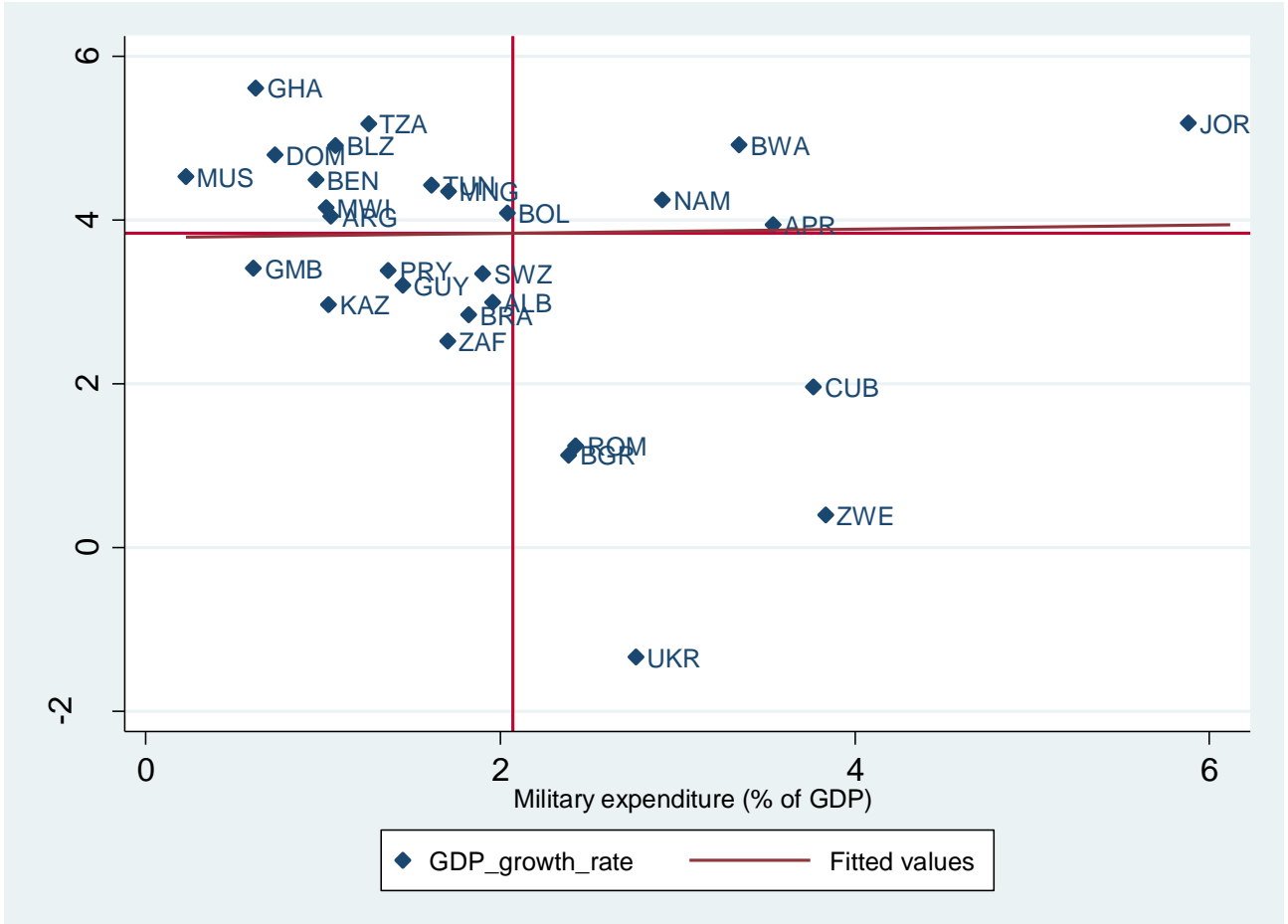

Note: Fitted line is based on linear regression of growth on military expenditure. 